\title{
Composition Characteristics of Gas Hydrate Produced Gas and Pretreatment Research
}

\author{
Shuren Yang1, Di Xu1, Liqun Xiu', Chao Duan², Boxue Pang1 \\ ${ }^{1}$ Department of Petroleum Engineering, Northeast Petroleum University, Daqing, China \\ ${ }^{2}$ CNOOC (China) Limited Zhanjiang Branch, Zhanjiang, China \\ Email: wonderdi@sina.com
}

Received 22 August 2014; revised 18 September 2014; accepted 6 October 2014

Copyright (C) 2014 by authors and Scientific Research Publishing Inc.

This work is licensed under the Creative Commons Attribution International License (CC BY). http://creativecommons.org/licenses/by/4.0/

(c) (i) Open Access

\begin{abstract}
To accelerate the pace of research and the use of alternative energy strategies Gas Hydrate, on the basis of previous studies, this paper analyzes the composition characteristics of Gas Hydrate produced gas. It provides technical support for our research and the use of Gas Hydrate. This eases the supply and demand of energy and reduces pollution of the atmospheric environment.
\end{abstract}

\section{Keywords}

Gas Hydrate, Gas Composition, Pretreatment Process, Technical Support

\section{Introduction}

Gas Hydrate is recognized as one of the world energy to succeed in nature, which has important strategic significance and enormous economic value. It is included in the key research topics in many developed and developing countries. Once the Gas Hydrate was successfully mined, research of ground gas processing technology will have great significance. Analysis of the produced gas composition characteristics can not only provide important information about Gas Hydrate accumulation mechanism, reserves, mineral scale, but also promote the progress of Gas Hydrate produced gas and other related ground pretreatment processes.

This paper will summarize combustible ice produced gas geochemical data and analysis and testing technical information, and then the gas composition of Gas Hydrate can be determined. Depending on the composition of Gas Hydrate, the pretreatment technology can be systematically studied, so that it can provide the ground support systems of Gas Hydrate produced gas a reference.

\section{Distribution of Resources and Reserves of Gas Hydrate}

Gas Hydrate is made from water and gas under the conditions of low temperature and high pressure. It is similar

How to cite this paper: Yang, S.R., Xu, D., Xiu, L.Q., Duan, C. and Pang, B.X. (2014) Composition Characteristics of Gas Hydrate Produced Gas and Pretreatment Research. Energy and Power Engineering, 6, 481-486.

http://dx.doi.org/10.4236/epe.2014.613041 
to ice, non-stoichiometric and crystalline clathrate compounds. Gas Hydrate is called "combustible ice” and "solid gas" because its appearance is very similar with ice or solid alcohol, and it is easy to be ignited. Under standard conditions, a unit volume of Gas Hydrate can store 160 to 180 per unit volume of natural gas. It is a new energy-efficient with a high energy density and it is shallow, large-scale and clean, etc. Therefore it is called the strategic resources that have the most promising commercial development in the 21st century.

\subsection{The Distribution of Gas Hydrate}

There are very rich reserves of Gas Hydrate on Earth. About 27 percent of the land (mainly in the freezing rock) and $90 \%$ of the sea all contain Gas Hydrate. The following two areas are most likely to form it:

1) High-latitude land (tundra) and the continental shelf. Gas Hydrate on land exists in the place that is in the depth of 200 - $2000 \mathrm{~m}$. It is mainly distributed beneath the permafrost of the high-latitude polar or at the edges of continental slopes and ridges, where the temperature is very low. Area of global polar permafrost regions is about $1.1 \times 10^{7} \mathrm{~km}^{2}$, of which the area of Qinghai-Tibet Plateau is about $1.588 \times 10^{6} \mathrm{~km}^{2}$.

2) Seabed. It is generally believed that when the depth of water is more than $500 \mathrm{~m}$, the temperature and pressure of seabed sediments will be able to meet the formation conditions of Gas Hydrate. Gas Hydrate in the sea is mainly present in the island slope, mainland slope and on the surface sediments or sedimentary of the ba$\sin$.

Currently, combustible ice is mainly distributed in the following locations:

1) The Bering Sea in Western Pacific, Okhotsk, trench of Kuril, Okinawa trough, the sea of Japan, trough of Japan Shikoku, Indonesia Sulawesi sea, Australia's north west sea and New Zealand's north island off the coast.

2) The east Pacific Ocean trough in China and the United States, in northern California offshore in Oregon, Peru trough.

3) Blake ridge outside waters of the Atlantic on the east coast of the United States, the gulf of Mexico, the Caribbean.

4) The Indian Ocean of the Oman gulf.

5) The deep lake.

6) The polar regions, such as the arctic Barents sea and Beauport sea, Antarctica’s Ross sea and Weddell sea.

7) Mainland permafrost regions, such as Russia’s Siberia, the Tibetan plateau in China.

\subsection{Reserves of Gas Hydrate}

Makogon indicated that there was Gas Hydrate in the permafrost within the territory of Russia, since then there has been two quite different views about the reserves of Gas Hydrate. One view is that: considering the dispersion and difficult exploitation of Gas Hydrate, the existence of gas hydrates can be ignored. Another argument is that: in the permafrost on the earth (27\% of the land area) and thermal stability of the sea area ( $90 \%$ of the sea area), the hydrate is widespread and should not be neglected. In the recent 30 years, research of scholars from all over the world on the global Gas Hydrate resources generally can be divided into three stages: the 1970s to the early 1980s (1017 - $1018 \mathrm{~m}^{3}$ level), the late 1980 s to the early $1990 \mathrm{~s}$ (1016 $\mathrm{m}^{3}$ level), since the late $90 \mathrm{~s}$ of the twentieth century to date (1014 - $1015 \mathrm{~m}^{3}$ level). Through the analysis we found that the earliest estimated results are bigger 2 - 3 orders of magnitude than that of today. Resource estimate value for Gas Hydrate with the change of time is shown in Figure 1.

Despite there is big differences in the global estimate value of Gas Hydrate resources, Now scientists from all over the world are more consistently agree with that its resources is $2 \times 10^{16} \mathrm{~m}^{3}$. If the reserves are converted into organic carbon of the earth's resources, it will account for more than half of the global total organic carbon. Therefore, as a potential energy, Gas Hydrate undoubtedly has great appeal. Table 1 shows the estimates of the amount of combustible ice in the oceans and permafrost.

According to the current level of exploration of combustible ice, identifying long-term resources to the amount of resources geology, geological reserves, and proven reserves will take some time. But what is certain is that, compared with conventional gas reserves of natural gas, combustible gas resource will great influence on the structure of energy in the future.

Compared with conventional natural gas reserves, the amount of Gas Hydrate of potential resources will have a huge impact on the future energy structure. 


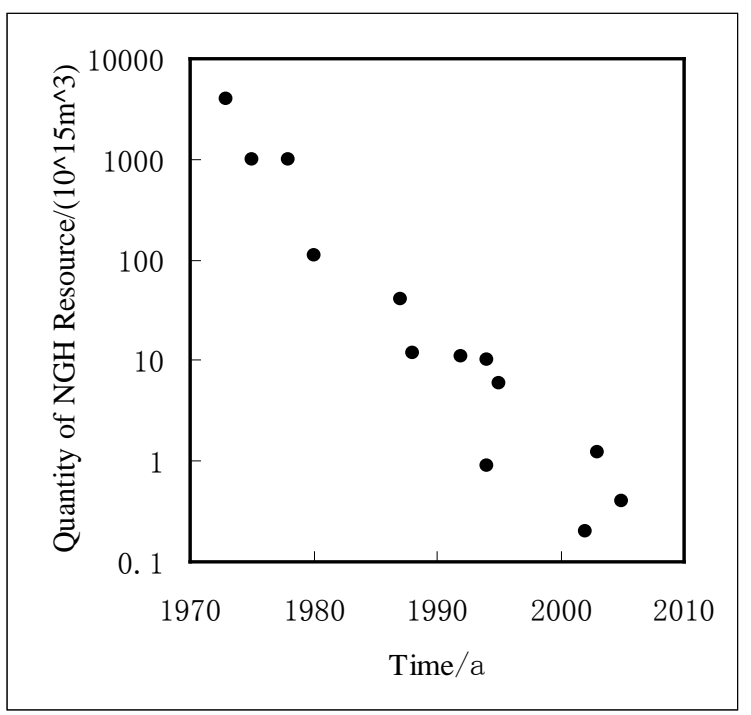

Figure 1. Resource estimation of Gas Hydrate in different periods.

Table 1. Estimates of Gas Hydrate in nature reserves.

\begin{tabular}{ccc}
\hline Permafrost hydrate & Marine hydrates $/ \mathrm{m}^{3}$ & References \\
\hline $5.7 \times 10^{13}$ & $(5.25) \times 10^{15}$ & Trofimuk (1977) \\
$3.1 \times 10^{13}$ & $3.1 \times 10^{15}$ & Melver (1982) \\
$3.4 \times 10^{16}$ & $7.6 \times 10^{18}$ & Dobrynin (1981) \\
$1.4 \times 10^{13}$ & & Meyer (1981) \\
$1.0 \times 10^{14}$ & $1.0 \times 10^{14}$ & Makogon (1981) \\
& $1.8 \times 10^{16}$ & Kvenvolden (1988) \\
$7.4 \times 10^{14}$ & $2.1 \times 10^{16}$ & MacDonal (1990) \\
& $(2.6-13.9) \times 10^{16}$ & Gornitz andFung (1994) \\
& $0.38 \times 10^{15}$ & Ginsburg and Soloviev (1995) \\
& $(0.38-1.0) \times 10^{15}$ & Soloviev (2002) \\
\hline
\end{tabular}

\section{Composition Characteristics of Produced Gas}

The data in Table 2 are the range of gas molecules and isotopic composition of Gas Hydrate in the following areas: Oregon coast [1], Vancouver island, Costa rice inshore coastal Sakhalin island, South Korea, the east China sea, Japan near shore, offshore, the Norwegian sea, gulf of Cadiz, Gabon, the gulf of Mexico shoreline, south Carolina, near shore, black sea, the sea of Marmora, the eastern Mediterranean, Alaska and Canada McKenzie and China Qinghai [2], etc.

From Table 2, it is not difficult to find that, gas molecules of Gas Hydrate existing in the nature mainly include $\mathrm{C}_{1}, \mathrm{C}_{2}, \mathrm{C}_{3}, \mathrm{I}-\mathrm{C}_{4}, \mathrm{n}-\mathrm{C}_{4}, \mathrm{I}-\mathrm{C}_{5}, \mathrm{n}-\mathrm{C}_{5}$, neo- $\mathrm{C}_{5}$, cycl- $\mathrm{C}_{5}, \mathrm{n}-\mathrm{C}_{6}$ and its isomer hydrocarbon gas molecules, and the conventional gas such as $\mathrm{CO}_{2}$ and $\mathrm{H}_{2} \mathrm{~S}$ molecular, then even some complex hydrate contains $\mathrm{C}_{6}+$ or $\mathrm{C}_{7}-\mathrm{C}_{9}$ heavy hydrocarbon molecules. In a word, all the characteristics of gas molecules can be roughly divided into two categories: one type of gas is composed mainly of methane $\left(C_{1}>99.9 \%\right)$, containing a small amount of $C_{2}$ and $\mathrm{C}_{3}$; range of another type of gas is wide, containing $\mathrm{C}_{1}-\mathrm{C}_{6}+$ paraffin, $\mathrm{CO}_{2}$ and $\mathrm{H}_{2} \mathrm{~S}$, etc.

\subsection{Composition Characteristics of Marine Gas Hydrate}

179 copies (Atlantic 73, Pacific 106) were published between 1999 and 2011 about gas molecules and isotopic 
Table 2. The content range of Gas Hydrate gas molecules and the isotopic composition.

\begin{tabular}{|c|c|}
\hline The gas composition & Composition range of molecular \\
\hline $\mathrm{C}_{1}$ & $46.01 \%$ - 99.999\% (n = 230) \\
\hline $\mathrm{C}_{2}$ & $0.00 \%-15.37 \%(n=230)$ \\
\hline $\mathrm{C}_{3}$ & $0.00 \%-21.05 \%(\mathrm{n}=230)$ \\
\hline $\mathrm{n}-\mathrm{C}_{4}$ & $0.00 \%-9.50 \%(n=221)$ \\
\hline $\mathrm{i}-\mathrm{C}_{4}$ & $0.00 \%-5.66 \%(n=207)$ \\
\hline $\mathrm{n}-\mathrm{C}_{5}$ & $0.00 \%-0.90 \%(n=110)$ \\
\hline $\mathrm{i}-\mathrm{C}_{5}$ & $\begin{array}{c}0.00 \%-1.49 \%(\mathrm{n}=112) \\
36.01 \%(\mathrm{n}=1)\end{array}$ \\
\hline neo- $C_{5}$ & $0.00 \%-0.20 \%(n=24)$ \\
\hline cycl-C ${ }_{5}$ & $0.00 \%-0.024 \%(n=13)$ \\
\hline $\mathrm{n}-\mathrm{C}_{6}$ & $0.00 \%-0.22 \%(\mathrm{n}=18)$ \\
\hline $\mathrm{C}_{6}^{+}$or $\mathrm{C}_{7}-\mathrm{C}_{9}$ & $0.00 \%-1.85 \%(n=18)$ \\
\hline $\mathrm{CO}_{2}$ & $0.00 \%-27.63 \%(n=105)$ \\
\hline $\mathrm{H}_{2} \mathrm{~S}$ & $0.00 \%-2.20 \%(n=90)$ \\
\hline
\end{tabular}

n: Statistic number of the sample.

composition data of worldwide submarine Gas Hydrate sample. Marine Gas Hydrate mainly exists in the depth of 390 - $3306 \mathrm{~m}$, some exists on the surface of sea bottom; others exist in the $330 \mathrm{~m}$ below the seabed. Gas molecules of marine Gas Hydrate mainly include $\mathrm{C}_{1}, \mathrm{C}_{2}$ and $\mathrm{C}_{3}, \mathrm{I}-\mathrm{C}_{4}, \mathrm{n}-\mathrm{C}_{4}, \mathrm{I}-\mathrm{C}_{5}, \mathrm{n}-\mathrm{C}_{5}$, neo- $\mathrm{C}_{5}, \mathrm{C}_{1}-\mathrm{C}_{5}$ hydrocarbon gas molecules and carbon dioxide $\left(\mathrm{CO}_{2}\right)$, hydrogen sulfide $\left(\mathrm{H}_{2} \mathrm{~S}\right)$, and other inorganic gas molecules. And most molecules are mainly methane hydrate whose content is greater than $99 \%$, other component content is lower, Vancouver island offshore Barkley canyon, Green valley of the gulf of Mexico, the Mississippi valley and Atwater canyon hydrate contains higher content of $\mathrm{C}_{2}-\mathrm{C}_{5}$. However, at present there are few reports that marine Gas Hydrate contains high molecular weight components such as $\mathrm{C}_{6}-\mathrm{C}_{7}$. Only Lu (2007) measured that the hydrate samples contain high content of $\mathrm{C}_{6}-\mathrm{C}_{7}$ in the Barkley Canyon, and at the same time proved that there is $\mathrm{H}$ structure hydrate in the samples [3].

\subsection{Composition Characteristics of Gas Hydrate in Inland Sea and Lake}

According to 35 copies of data from gas molecules and isotopic composition of Gas Hydrate in inland seas and lakes between 1999 to 2011, it is discovered that natural Gas Hydrate of Inland sea and lake exists 667 - $2050 \mathrm{~m}$ in depth. The depth of sample in sea bottom was relatively shallow, between $0.11 \mathrm{~m}$ and $7.15 \mathrm{~m}$. Inland sea and lake is rich in natural gas hydrate, containing $\mathrm{C}_{1}-\mathrm{C}_{9}, \mathrm{CO}_{2}$, etc. but $\mathrm{H}_{2} \mathrm{~S}$ components are not checked out. $\mathrm{C}_{1}$ content in the sample is more than $95 \%$, and other content of components is lower, but individual abnormal $\mathrm{C}_{5}$ content in natural Gas Hydrate samples is as much as $36.01 \%$ in the Sea of Marmara [4].

\subsection{Composition Characteristics of Terrestrial Permafrost Gas Hydrate}

According to 30 copies of data from gas molecules and isotopic composition of Gas Hydrate in terrestrial permafrost from 1999 to 2011, it is discovered that there is little Gas Hydrate in terrestrial permafrost. The buried depth of Gas Hydrate is deep (134 m - $134 \mathrm{~m}$ ), and molecular species is relatively more, containing $\mathrm{C}_{1}-\mathrm{C}_{6}{ }^{+}$, $\mathrm{CO}_{2}$, etc., but $\mathrm{H}_{2} \mathrm{~S}$ components are not checked out.

\section{Pretreatment Process}

The process of natural gas processing is necessary when it is separated from the oil and gas field separator. Then natural gas is allowed to enter distribution pipe after processing. So this is a very significant component of natu- 
ral gas industry. The pretreatment process of Gas Hydrate produced gas can consult the existing gas treatment process, as shown in Figure 2.

It should be emphasized that not all of the gas experiences the process in Figure 2. For example, if the acid component content in the produced gas is very small, which is already in line with the quality index of the natural gas commodity, it is not necessary to remove the acid gas. If ethane and heavier hydrocarbons in produced gas components are very few, the produced gas can be directly turned into liquefied natural gas (LNG) after pretreatment, etc.

According to composition of Gas Hydrate, pretreatment process is mainly divided into acid process and dehydration process.

\subsection{Desulfurization Processes of Gas Hydrate Produced Gas}

Desulfurization methods of Natural gas can generally be divided into chemical solvent method, physical method, chemical solvent-physical solvent method, direct conversion and other types. Amine method (Figure 3) is the main gas desulfurization technology. Different solution with MDEA as main ingredients is a good natural gas desulfurizer.

Under the control of economic factors, compared with the amine method + Claus + SCOT traditional crafts, direct catalysis and biological desulfurization method is technology for low sulfur gas desulfurization and sulfur recovery. The biological desulfurization method is alternative desulfurization technology for low sulfur gas.

\subsection{Dehydration Process Gas Hydrate Produced Gas}

Natural gas dehydration refers to removing water vapor from natural gas or removing dissolved water from natural gas condensate (NGL). The purposes of the dehydration are: 1) Prevent the occurrence of gas hydrates and

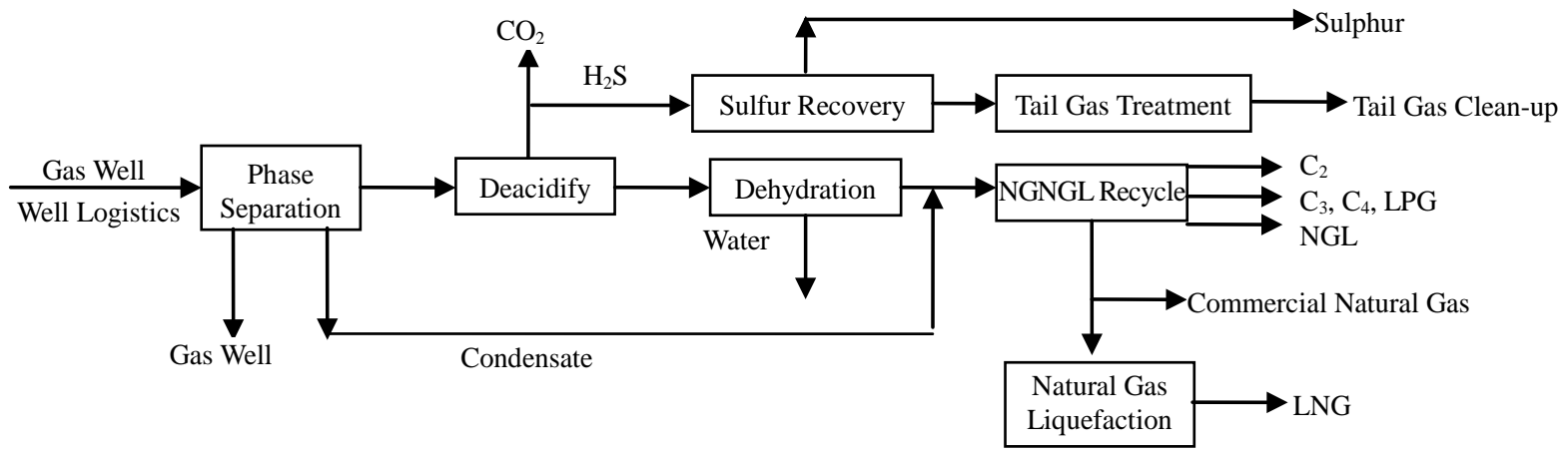

Figure 2. Schematic diagram of natural gas process.

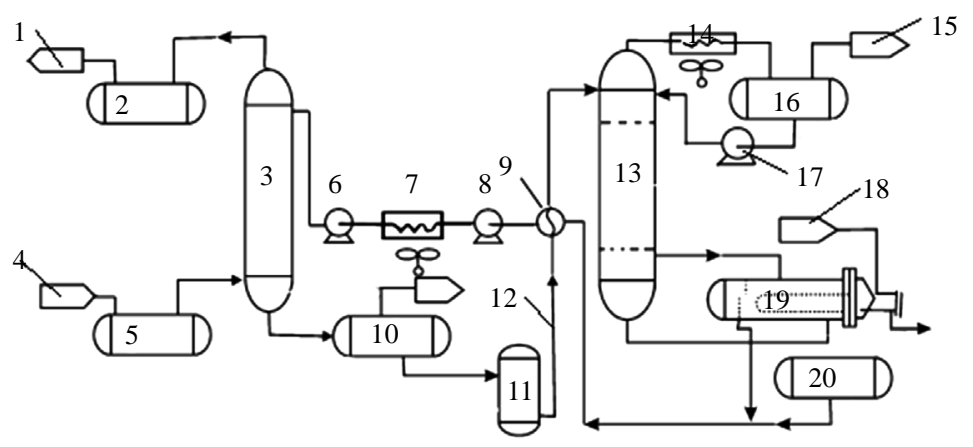

1—clean gas; 2-clean gas separator; 3-absorption tower; 4-sulphur-bearing gas; 5-feed gas separator; 6-alcohol amine solution pump; 7-solution cooler; 8-booster pump; 9-lean—rich solution heat exchanger; 10-flash tank; 11—filter; 12-flash steam; 13-regeneration tower; 14—overhead condenser; 15—sour gas; 16-backflow collecting cans; 17-backflow pump; 18-heat source; 19-reboiler; 20-buffer tank.

Figure 3. The basic technological process of amine system [5]. 
liquid water in the process of handling, storage and transportation. 2) Make it conform to the water content index of the products of natural gas. 3) Prevent corrosion. Therefore, the process of dehydration is needed in the natural gas dew point control (or deoiling dehydration), gas condensate recovery, liquefied natural gas (LNG) and compressed natural gas production. The dehydration methods of natural gas include absorption method, adsorption method, low temperature method, membrane separation, gas steam formulation and distillation etc.

\section{Conclusions}

1) Gas compositions of marine Gas Hydrate mainly include $\mathrm{C}_{1}$ - $\mathrm{C}_{5}$ hydrocarbons, $\mathrm{CO}_{2}$ and $\mathrm{H}_{2} \mathrm{~S}$, less $\mathrm{C}_{6}+$; Inland sea and lake is rich in natural gas hydrate, containing $\mathrm{C}_{1}-\mathrm{C}_{9}, \mathrm{CO}_{2}$, etc. but $\mathrm{H}_{2} \mathrm{~S}$ components are not checked out.; There are also many gas compositions of terrestrial permafrost Gas Hydrate: mainly $\mathrm{C}_{1}-\mathrm{C}_{6}$ hydrocarbons, $\mathrm{CO}_{2}, \mathrm{H}_{2} \mathrm{~S}$ components are not checked out. According to the composition of methane carbon isotope, it shows that, marine Gas Hydrate $<$ Gas Hydrate in Inland sea and lake $<$ Composition characteristics of terrestrial permafrost Gas Hydrate.

2) According to the different gas composition, the ground treatment system of Gas Hydrate produced gas for the decomposition gas can be different. When there is less acidic ingredient, desulfurization process is not necessary. When acidic component is large, it not only needs the process for acid treatment but also the process for sulfur recovery.

\section{Funding}

The source of the project: supported by Northeast Petroleum University Innovation Foundation for Postgraduate. The project number: YJSCX2014-014NEPU.

\section{References}

[1] Xiao, G. and Bai, Y.H. (2013) Natural Gas Hydrate-An Ice Can Burn. Wuhan University Press, Wuhan, 13-14.

[2] Lu, Z.Q., Zhui, Y.H., Zhang, Y.Q. (2010) Gas Formation Study of Gas Hydrates in Qilian Mountain Regions of Qinghai Province. Modern Geology, 24, 581-588.

[3] Lu, H, Seo, Y, Lee, J, et al. (2007) Complex Gas Hydrate from the Cascadia Margin. Nature, 445, 303-306. http://dx.doi.org/10.1038/nature05463

[4] Ruffine, L., Donval, J.P., Charlou, J.L., et al. (2009) Gas Hydrates from the Sea of Marmara: Variability in Composition and Origin of the Hydrate-Forming Gases. American Geophysical Union, Fall Meeting.

[5] Wang, K.Y. (2005) Natural Gas Purification Process: The Decarburization Desulfurization, Dehydration, Sulfur Recovery and Tail Gas Treatment. Petroleum Industry Press, Beijing. 